\title{
Keefektifan Model Pembelajaran Role Playing Berbantu Media Multiply Cards terhadap Hasil Belajar Siswa
}

\author{
*Sutria Amina Kasanah¹, Aries Tika Damayani², Rofian³
}

${ }^{123}$ Jurusan Pendidikan Guru Sekolah Dasar, Universitas PGRI Semarang, Indonesia

\section{A R T I C L E I N F O \\ Article history: \\ Received 15 August 2019 \\ Received in revised form \\ 20 September 2019 \\ Accepted 10 October 2019 \\ Available online 30 \\ November 2019 \\ Kata Kunci: \\ model role playing, multiply cards}

Keywords:

role playing model, multiply cards

\begin{abstract}
A B S T R A K
Masih rendahnya nilai mata pelajaran siswa kelas $\mathrm{V}$ SD serta kurangnya penggunaan model pembelajaran yang menarik sehingga antusias siswa dalam mengikuti pembelajaran kurang dan siswa cenderung bersikap pasif merupakan sala satu penyebab rendahnya hasil belajar siswa kelas V SD. Dari hal tersebut, tujuan dilakukannya penelitian ini adalah untuk mengetahui efektifitas model pembelajaran Role Playing berbantu media MultiplyCards terhadap hasil belajar siswa kelas V SD. Jenis penelitian ini adalah penelitian kuantitatif dengan menggunakan Pretest-Posttest one-Group Design. Hasil analisis data hasil belajar Pretest dan posttest dengan uji-t bahwa diperoleh dengan nilai rata-rata pretest sebesar 51,471 dan rata-rata nilai posttest sebesar 81,647 . Dengan $N=17$, Diperoleh thitung $=6,881$ dengan taraf signifikan $5 \%$ sebesar 2,035. Karena thitung $=6,881>$ ttabel $=2,035$ Maka hal ini menunjukkan bahwa uji t mempunyai efek yang signifikan.
\end{abstract} Hal ini menunjukkan bahwa terdapat efek dari pembelajaran Model Role Playing berbantu media ultiply Cards. Saran yang dapat peneliti sampaikan adalah guru harus lebih kreatif dan inovatif dalam melakukan pembelajaran dikelas agar dapat meningkatkan keaktifan serta minat belajar peserta didik dalam mengikuti pembelajaran.

\begin{abstract}
A B S T R A C T
The background in this study is the low value of subjects in class V SDN Kaliwiru Semarang and the lack of use of an attractive learning model so that students are less enthusiastic in participating in learning and students tend to be passive. The problem examined in this study is "is the Role Playing learning model assisted by the Multiply Cards media effective towards the learning outcomes of fifth grade students at Kaliwiru Semarang Elementary School?". The purpose of this study was to determine the effectiveness of the MultiplyCards media-assisted Role Playing learning model on student learning outcomes in the fifth grade SDN Kaliwiru Semarang. This type of research is quantitative research using Pretest-Posttest one-Group Design. The results of data analysis of pretest and posttest learning outcomes with t-test that obtained with an average pretest score of 51.471 and an average posttest value of 81.674. With $N=17$, obtained tcount $=6.881$ with a $5 \%$ significance level of 2.035. Because tcount $=6.881>t$ table $=2.035$ Then this shows that the $t$ test has a significant effect. This shows that there is an effect of learning the Role Playing Model using media ultiply cards. Suggestions that researchers can convey is that teachers must be more creative and innovative in conducting classroom learning so that they can increase the activeness and learning interest of students in participating in learning.
\end{abstract}

\section{Pendahuluan}

Pendidikan sangatlah penting bagi peserta didik, dengan pendidikan peserta didik mampu menguasai pengetahuan dan keterampilan yang kelak akan berguna di masyarakat. Peserta didik diharapkan mampu menerapkan pengetahuan dan keterampilannya kelak untuk membangun bangsa, sehingga peserta didik tidak tertinggal oleh ilmu pengetahuan dan teknologi yang saat ini berkembang pesat sesuai tuntutan zaman. (Ernani, 2016) Pendidikan merupakan faktor utama dalam membentuk

Copyright () Universitas Pendidikan Ganesha. All rights reserved. 
pribadi manusia. Karena, pendidikan merupakan sebuah proses bagi seseorang untuk mendapatkan pengetahuan, pengalaman dan tingkah laku yang membentuk baik atau buruknya pribadi seseorang. Selain itu, peranan pendidikan bagi seseorang juga merupakan faktor penting dalam memperoleh kemampuan dan keterampilan siswa untuk memecahkan masalahan kehidupannya. Pendidikan merupakan kebutuhan manusia. Tanpa sadar manusia akan membutuhkan pendidikan itu dimasyarakat terutama pada seorang anak. Berdasarkan Sistem Pendidikan Nasional (Depdiknas, 2007) Pendidikan adalah usaha sadar dan terencana untuk mewujudkan suasana belajar dan proses pembelajaran agar peserta didik secara aktif mengembangkan potensi dirinya untuk memiliki kekuatan spritual keagamaan, pengembangan diri, kepribadian, kecerdasan, akhlak mulia, serta keterampilan yang diperlukan dirinya, masyarakat, bangsa, dan negara. Adapun pengertian pendidikan Menurut para ahli sebagai berikut : Thompson (Sudharto, 2009) menyatakan pendidikan adalah pengaruh lingkungan atau individu untuk menghasilkan perubahan-perubahan yang tetap (permanen) didalam kebiasaan-kebiasaan, tingkahlakunya, pemikirannya, dan sikapnya. Berdasarkan pendapat para alih di atas pendidikan merupakan bagian penting dalam kehidupan manusia. Pendidikan itu sebagai proses mendidik dan dididik, dilingkungan sekolah orang yang mendidik adalah guru dan orang yang dididik adalah siswa. Dalam proses pelaksanaan pembelajaran guru sangat berperan penting dan menjadi faktor penentu keberhasilan proses belajar dalam mencapai hasil belajar siswa yang baik.

Pendidikan di Sekolah Dasar memiliki peran yang sangat penting dalam membentuk kemampuan dasar, keterampilan dasar dan mengembangkan pengetahuan pada siswa serta mempersiapkan mereka untuk mengikuti jenjang pendidikan yang lebih tinggi. Untuk itu, kualitas pendidikan khususnya pendidikan di Sekolah Dasar harus selalu ditingkatkan. Upaya yang dapat dilakukan untuk meningkatkan kualitas pendidikan Sekolah Dasar adalah dengan meningkatkan mutu proses pembelajaran maupun meningkatkan kompetensi guru dalam mendidik. Peningkatan mutu proses pembelajaran dapat dilakukan dengan mengembangkan mata pelajaran yang sudah ada dan upaya peningkatan kompetesi guru dalam mendidik dapat ditempuh dengan peningkatan kualitas guru dalam proses pembelajaran dengan menggunakan berbagai metode pembelajaran sehingga siswa dapat dengan mudah menyerap materi pada saat pembelajaran sedang berlangsung.

(Sha'adhah et al., 2013) Matematika adalah suatu bidang ilmu yang melatih penalaran supaya berpikir logis, sistematis dalam menyelesaikan masalah dan membuat keputusan. Siswa menganggap matematika tidak menarik dan penuh rumus, sehingga mengakibatkan siswa kurang berhasil dalam belajar matematika. Dalam proses pembelajaran matematika siswa sering melakukan kesalahankesalahan yang mengakibatkan siswa tidak tuntas dalam belajar dan tujuan yang ditetapkan tidak tercapai (Niken, Susanto, 2012). Matematika merupakan salah satu bidang studi yang ada pada semua jenjang pendidikan, mulai dari tingkat sekolah dasar hingga perguruan tinggi. Hal ini menunjukkan bahwa matematika mempunyai peran yang sangat penting, terutama pada jenjang pendidikan sekolah dasar. (Sundayana, 2013) matematika merupakan salah satu komponen dan serangkaian mata pelajaran yang mempunyai peran penting dalan pendidikan. Rendahnya hasil belajar Matematika di kelas V SDN Kaliwiru Semarang dipengaruhi banyak faktor baik dari siswa maupun guru. Faktor yang berasal dari siswa adalah siswa menganggap bahwa mata pelajaran Matematika merupakan mata pelajaran yang sulit dipahami sehingga tidak sedikit siswa di kelas V takut dengan mata pelajaran Matematika. Dengan keadaan yang demikiian mengakibatkan hasil belajar pada mata pelajaran Matematika sering rendah. Faktor yang kedua berasal dari guru, yaitu guru belum menggunakan inovasi media pembelajaran matematika pada pembelajaran perkalian, sehingga pembelajaran cenderung monoton karena pembelajaran berpusat pada guru. Berdasarkan permasalahan yang sudah didapatkan saat melakukan observasi dan wawancara di SDN Kaliwiru Semarang, untuk menumbuhkan sifat antusiasme siswa dalam pembelajaran matematika diperlukan pembelajaran yang menyenangkan bagi siswa. Pembelajaran yang menyenangkan dapat dilakukan dengan berbagai cara, salah satunya dengan menggunakan model pembelajaran. Model pembelajaran yang inovatif dan menyenangkan dapat membuat siswa lenbih antusias dalam pembelajaran seperti menggunakan model role playing.

Model Role Playing merupakan model yang tepat untuk melatih daya ingat pada siswa. Model Role Playing suatu penguasaan materi melalui pengembangan imajinasi dan penghayatan siswa. Pengembangan imajinasi dan penghayatan ini dilakukan siswa dengan memerankan tokoh. Permainan ini pada umumnya dilakukan lebih dari satu orang, hal itu bergantung kepada apa yang diperankan (Hamdani, 2011). Adapun keuntungan dalam menggunakan model Role Playing ini adalah : 1) siswa bebas mengambil keputusan dan berekspresi secara utuh; 2) permainan merupakan penemuan yang mudah dan dapat digunakan dalam situasi dan waktu yang berbeda; 3)guru dapat mengevaluasi permasalahan setiap siswa melalui pengamatan pada saat melakukan permainan ; 4) permainan merupakan pengalaman belajar yang menyenangkan bagi anak (Hamdani, 2011). Dengan demikian model Role Playing ini salah satu solusi yang bisa digunakan dalam melatih keterampilan berhitung siswa, kelebihan Role Playing 
menjadikan pengalaman belajar yang menyenangkan dengan itu siswa mampu menghitung sehingga siswa menjadi tidak pasif dan aktif dalam proses pembelajaran. Kegiatan Role playing akan lebih optimal bila ditunjang media pembelajaran. Peneliti memilih media Multiply Cards untuk menunjang proses pembelajaran. (Aqib, 2013) Metode role playing atau bermain peran adalah metode yang melibatkan interaksi antara dua siswa atau lebih tentang suatu topik atau situasi. (Roestiyah, 2012) Metode role playing atau bermain peran adalah dimana siswa bisa berperan atau memainkan peranan dalam dramatisasi masalah sosial/psikologis itu. (Djamarah, 2010) Model role playing (bermain peran) dapat dikatakan sama dengan sosiodrama, yang pada dasarnya mendramatisasikan tingkah laku dalam hubungannya dengan masalah sosial. Bermain peran pada prinsipnya merupakan pembelajaran untuk menghadirkan peran-peran yang ada dalam dunia nyata ke dalam suatu pertunjukan peran di dalam kelas, yang kemudian dijadikan sebagai bahan refleksi agar peserta memberikan penilaian terhadap pembelajaran yang telah dilaksanakan dan kemudian memberikan saran / alternatif pendapat bagi pengembangan peran-peran tersebut. (Tarigan, 2017) Model role playing adalah uatu model pembelajaran dengan menugaskan siswa untuk memerankan suatu tokoh yang ada dalam materi atau peristiwa yang diungkapkan dalam bentuk cerita sederhana yang telah dirancang oleh guru. (Nurhasanah et al., 2016) Penggunaan metode role playing di sekolah menjadikan siswa pribadi yang imajinatif, mempunyai minat luas, mandiri dalam berfikir, ingin tahu, penuh energi dan percaya diri serta siswa mampu meningkatkan kerjasamanya. Selain itu, siswa dapat melatih, memahami dan mengingat bahan materi yang akan disampaikan atau didramakan sesuai denga gaya bahasa dan gaya belajar siswa. Menurut Shaftels (Sumaatmadja, 2007) yaitu penjelasan umum yaitu guru menjelaskan secara umum penggunaan metode role playing serta materi yang akan diperankan, tahapan selanjutnya yaitu memilih para pelaku untuk bermain peran, kemudian menentukan pengamat (observer) yang bertugas untuk mengamati penampilan permainan peran serta memberikan penilaian, selanjutnya menentukan jalan cerita yang dimainkan, tahap selanjutnya yaitu pelaksanaan (main), diskusi dan penilaian yang dilakukan observer, kelompok bermain peran memainkan peran ulang, kelompok observer melakukan diskusi ulang, terakhir berbagi pengalaman dan kesimpulan.

Media pembelajaran operasi hitung perkalian memiliki banyak variasa salah satunya media permainan kartu. Permainan kartu khususnya permainan kartu angka menurut Tahir dalam (Rini et al., 2019) suatu alat bantu yang digunakan dan di buat dengan bertuliskan bilangan oleh guru matematikadalam mengajarkan materi penjumlahan, pengurangan, perkalian dan pembagian. Sedangkan untuk media Multiply Cards adalah salah satu media modifikasi kartu yang berisi operasi hitung perkalian dua bilangan cacah dan hasil operasi hitung perkalian yang ditulis secar berselang-seling. Media multiply cards ini akan memudahkan siswa untuk mengingat dan memahami materi yang dipelajari.

Tabel 1. Persentase Nilai Ulangan Harian Matematika

\begin{tabular}{ccccccc}
\hline \multirow{2}{*}{ No } & Rentang & Jumlah & \multicolumn{4}{c}{ Ketuntasan } \\
\cline { 5 - 7 } & Nilai & Siswa & Tuntas & Persentase & Tidak Tuntas & Persentase \\
\hline 1 & $0-44$ & 2 & - & - & 2 siswa & $7 \%$ \\
2 & $45-64$ & 19 & - & - & 19 siswa & $57 \%$ \\
3 & $65-84$ & 10 & 10 siswa & $29 \%$ & - & - \\
4 & $85-100$ & 2 & 2 siswa & $7 \%$ & - & - \\
\hline & Jumlah & $\mathbf{3 3}$ & $\mathbf{1 2}$ & $\mathbf{3 6 \%}$ & $\mathbf{2 1}$ & $\mathbf{6 4 \%}$ \\
\hline
\end{tabular}

Dari Tabel diatas dapat disimpulkan bahwa hasil belajar siswa dalam pembelajaran Matematika masih dibawah KKM. KKM di SDN Kaliwiru Semarang adalah 65. Dari 33 siswa yang ada dikelas V, 12 siswa mendapatkan nilai di atas KKM sedangkan 21 siswa mendapatkan nilai kurang dari KKM. Atau dapat diartikan 36\% yang mendapatkan nilai tuntas, sedangkan $64 \%$ siswa belum tuntas.

Berdasar masalah yang ada diatas maka peneliti tertarik untuk melakukan penelitian yang berjudul “Kefektifan Model Role Playing Berbantu Media Multiply Cards Terhadap Hasil Belajar Matematika Kelas V SDN Kaliwiru Semarang".

\section{Metode}

(Sugiyono, 2017) Metode penelitian pada dasasrnya cara ilmiah untuk mendapatkan data dengan tujuan dan kegunaan tertentu. Metode penelitian yang digunakan adalah metode eksperimen yang termasuk dalam metode kuantitatif. Metode kuantitafif adalah metode penelitian yang mengolah data yang telah didapatkan dengan menggunakan statistik. 
Desain penelitian yang digunakan dalam penelitian ini adalah Pre Eksperimental Desain dengan bentuk desain One-Group Pretest-Prosttest Desain. Pada desain ini terdapat pretest sebelum diberiperlakuan. Dengan demikian hasil perlakuan dapat diketahui lebih akurat, karena membandingkan dengan keadaan sebelum diberi perlakuan (Sugiyono, 2017). Design ini dapat di gambarkan sebagai berikut:

\section{$01 \times 02$}

Keterangan:

$01=$ Nilai pretest (Sebelum di beri perlakuan model Role Playing berbantu media Multiply Card)

$02=$ Nilai Posttest (Setelah di beri perlakuan model Role Playing berbantu media Multiply Card)

02-01 = Efektifitas model Role Playing berbantu media Multiply Card terhadap hasil belajar siswa

Siswa kelas V akan diberi pretest untuk mengetahui kondisi awal sebelum diberi perlakuan. Setelah hasil pretest didapat, barulah siswa kelas eksperimen diberi perlakuan dengan menggunakan model pembelajaran Role Playing berbantu media Multiply Cards. siswa diberi posttest untuk mendapatkan hasil akhir setelah siswa diberi perlakuan. penelitian.

\section{Hasil dan Pembahasan}

a. Nilai Awal

Deskripsi nilai awal hasil belajar kelas V SDN Kaliwiru Semarang. Jumlah skor dengan responden 17 orang adalah 875 , rata-rata skor adalah 51,47

Tabel 2. Distribusi Frekuensi Nilai Pretest

\begin{tabular}{ccc}
\hline Interval & Frekuensi & presentase \\
\hline $31-42$ & 7 & $41,2 \%$ \\
$43-54$ & 2 & $11,8 \%$ \\
$55-66$ & 3 & $17,6 \%$ \\
$67-78$ & 4 & $23,5 \%$ \\
$79-90$ & 1 & $5,9 \%$ \\
\hline
\end{tabular}

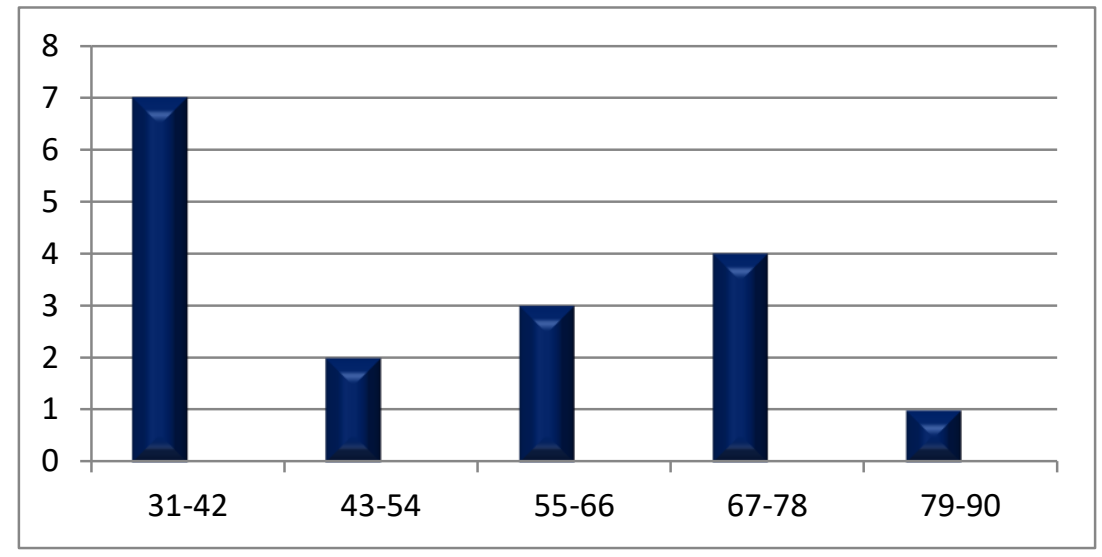

Gambar 1.

Diagram Histrogram Nilai Pretest

\section{b. Nilai Akhir}

Deskripsi nilai akhir Hasil Belajar kelas V SDN Kaliwiru Semarang. Jumlah skor dengan responden 17 orang adalah 1388 , rata-rata skor adalah 81,647. 
Tabel 2. Distribusi Frekuensi Nilai Postest

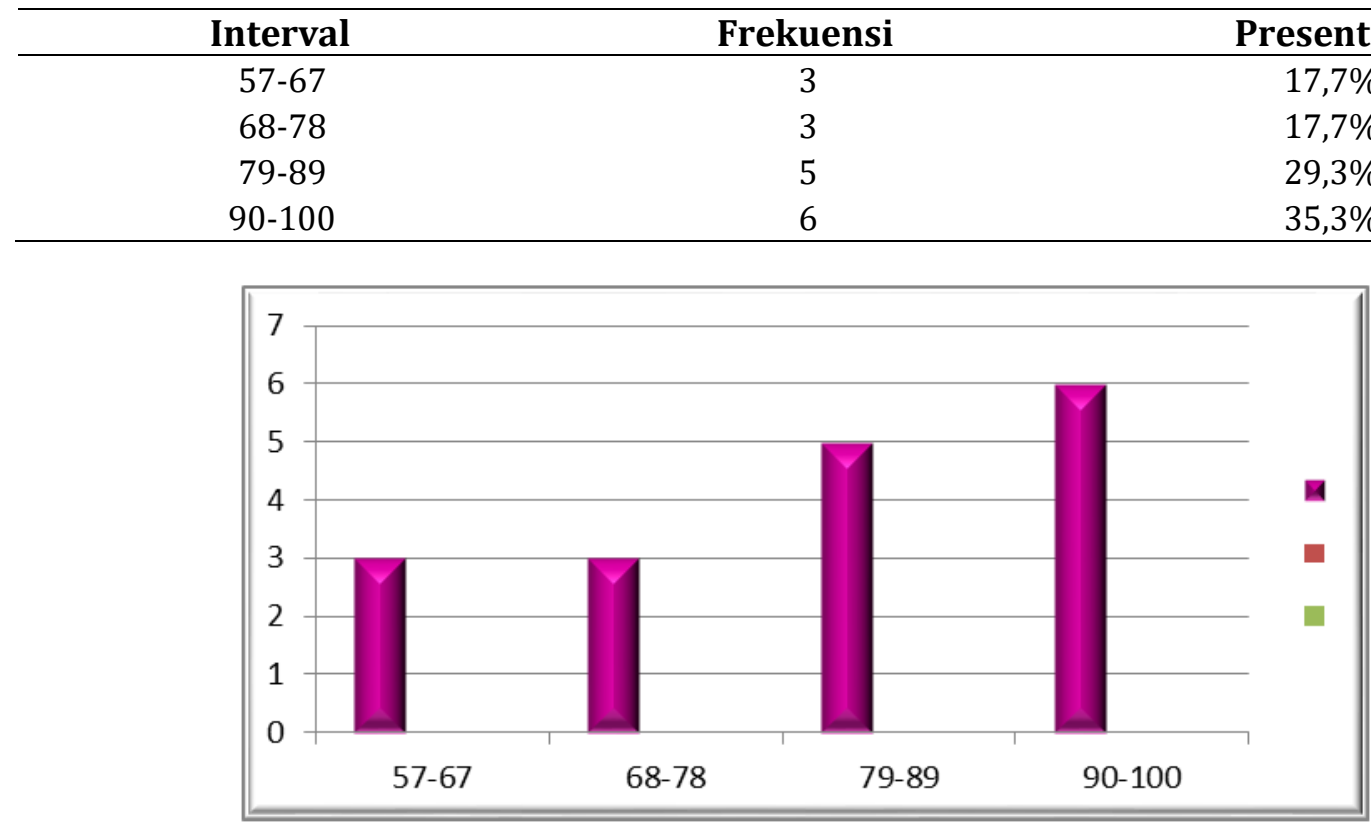

Gambar 2.

Diagram Histrogram Nilai Postest

\section{c. Perbandingan Nilai Awal dan Akhir Keterampilan berbicara}

Tabel 3. Nilai Pretest dan Postest Hasil Belajar Siswa

\begin{tabular}{cccccc}
\hline $\begin{array}{c}\text { Jenis } \\
\text { Tes }\end{array}$ & $\begin{array}{c}\text { Nilai } \\
\text { Terendah }\end{array}$ & $\begin{array}{c}\text { Nilai } \\
\text { Tertinggi }\end{array}$ & Rata-rata & Tuntas & $\begin{array}{c}\text { Tidak } \\
\text { Tuntas }\end{array}$ \\
\hline Pretest & 31 & 80 & 51,471 & $5(29,41 \%)$ & $12(70,59 \%)$ \\
Posttest & 57 & 100 & 81,647 & $14(82,35 \%)$ & $3(17,65 \%)$ \\
\hline
\end{tabular}

Sumber: Penelitian (2019)

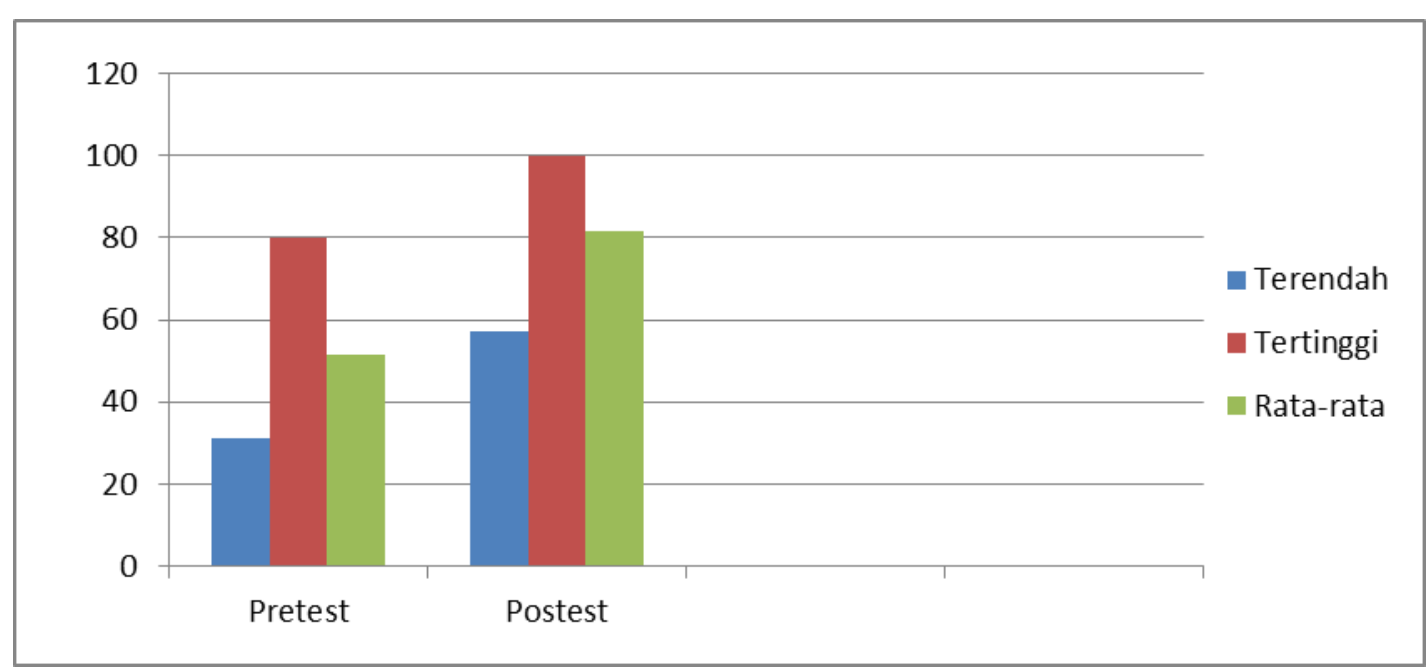

\section{Gambar 3.}

Diagram Nilai Hasil Belajar Matematika

Berdasarkan Tabel 3 dan Gambar 3 hasil penelitian tersebut maka diperoleh nilai terendah pada uji pretest sebesar 31, dan nilai tertinggi sebesar 80 dan nilai rata-rata sebesar 51,471. Ketuntasan hasil belajar pada uji pretest siswa yang tuntas mencapai KKM 75 sebanyak 5 siswa dan siswa yang tidak tuntas 
sebanyak 12 siswa. Sedangkan pada hasil posttest diperoleh nilai terendah sebesar 57, nilai tertinggi 100 dan nilai rata-rata sebesar 81,647. Ketuntasan hasil belajar pada uji posttest siswa yang tuntas memcapai KKM 75 sebanyak 14 dan siswa yang tidak tuntas sebanyak 3 siswa. Dengan melihat data hasil penelitian tersebut menunjukkan bahwa telah terjadi peningkatan hasil penelitian belajar yang signifikan setelah diberi model pembelajaran Role Playing berbantu media Multiply Cards.

\section{d. Uji Persyaratan Analisis Data}

Uji normalitas digunakan untuk mengetahui apakah sampel dari populasi berdistribusi normal atau tidak, untuk menguji normalitas ini digunakan uji lilliefors. Misalkan sampel acak dengan menggunakan $\mathrm{X}_{1}, \mathrm{X}_{2}, \ldots, \mathrm{Xn}$. Berdasarkan sampel ini akan diuji hipotesis nol danhipotesis alternatifnya, yaitu:

$\mathrm{H}_{0}$ : Sampel tidak berasal dari populasiyangberdistribusi normal.

$\mathrm{H}_{\mathrm{a}}$ : Sampel berasal daripopulasiyangberdistribusi normal.

Adapun langkah-langkah untuk menguji kenormalan suatu sampel yaitu kriteria pengujian hipotesis pada uji lilliefors yaitu apabila diperoleh nilai $\mathrm{L}_{0} \leq \mathrm{L}_{\text {tabel }}$ maka $\mathrm{H}_{0}$ diterima atau sampel berasal dari populasi yang berdistribusi normal. Hasil uji normalitas diperoleh nilai pada tabel 4 berikut:

Tabel 4. Hasil Uji Normalitas

\begin{tabular}{|c|c|c|c|}
\hline Hasil Belajar & $\mathrm{L}_{\text {tabel }}$ & $\mathrm{L}_{\text {hitung }}$ & Keterangan \\
\hline Pretest & 0,206 & 0,153 & Normal \\
\hline Posttest & 0,206 & 0,112 & Normal \\
\hline
\end{tabular}

Berdasarkan Tabel 4. dengan $\mathrm{n}=17$ dengan taraf signifikan sebesar $5 \%$ maka diperoleh nilai Ltabel $=0,206$. Hasil uji normalitas awal dengan menggunakan hasil belajar pretest pada tabel 4.2 menunjukkan nilai Lhitung $=0,153$. Sedangkan pada hasil uji normalitas akhir diperoleh nilai Lhitung $=0,112$. Dengan demikian hasil uji normalitas dengan menggunakan uji lilliefors diperoleh nilai 0,153 $\leq 0,206$ dan 0,112 $\leq$ 0,206 maka Lhitung $\leq$ Ltabel, maka dapat disimpulkan bahwa sampel berasal dari populasi yang berdistribusi normal.

\section{e. Uji Hipotesis}

Uji hipotesis pada penelitian ini, peneliti menggunakan uji t-test yang dilakukan untuk membandingkan hasil data dari perhitungan pretest dan pottest serta menentukan ada atau tidaknya perbedaan sebagai akibat dari perlakuan X yaitu pembelajaran mengunakan model pembelajaran Role Playing berbantu media Multiply Cards terhadap hasil belajar dianalisis dengan uji t-test. Hipotesis yang diajukan dalam penelitian ini adalah terdapat efektifitas model pembelajaran Role Playing berbantu media Multiply Cards terhadap keterampilan hasil belajar SDN Kaliwiru Semarang.

$\mathrm{H}_{\mathrm{o}}$ : Tidak ada efek model pembelajaran Role Playing berbantu media Multiply Cards terhadap hasil belajar siswa kelas V SDN Kaliwiru Semarang.

$\mathrm{H}_{\mathrm{a}}$ : Model pembelajaran Role Playing berbantu media Multiply Cards efektif meningkatkan hasil belajar siswa kelas V SDN Kaliwiru Semarang.

Tabel 5. Hasil Perhitungan Uji-t

\begin{tabular}{lccccc}
\hline \multicolumn{1}{c}{ Subyek } & $\begin{array}{c}\text { Hasil } \\
\text { Belajar }\end{array}$ & Rata-rata & $\mathbf{N}$ & $\mathbf{T}_{\text {hitung }}$ & $\mathbf{T}_{\text {tabel }}$ \\
\hline Kelas V SDN Kaliwiru & Pretest & 51,471 & 17 & 6,881 & 2,035 \\
Semarang & Posttest & 81,647 & 17 & 6,881 & 2,035 \\
\hline
\end{tabular}

Berdasarkan Tabel 5 analisis data nilai Pretest dan posttest dengan uji-t bahwa diperoleh dengan nilai rata-rata pretest 51,471 dan rata-rata nilai posttest sebesar 81,647. Dengan $N=17$, Diperoleh thitung $=6,881$ dengan taraf signifikan 5\% sebesar 2,035. Karena thitung =9,765272 $>$ ttabel $=1,729$, Maka hal ini menunjukkan bahwa uji t mempunyai efek yang signifikan. Hal ini menunjukkan bahwa terdapat efek dari pembelajaran Model Role Playing berbantu media Multiply Cards. 
Berdasarkan analisis data yang telah diuraikan diatas, dapat diketahui bahwa sebelum pelaksanaan penelitian dilakukan, peneliti melakukan analisis awal terlebih dahulu, dengan melakukan uji normalitas menggunakan uji Liliefors. Data awal pada penelitian ini adalah nilai pretes yang diperoleh dari siswa kelas V SDN Kaliwiru Semarang. sebelum soal pretest diberikan terlebih dahulu peneliti memberikan soal pretest tersebut kepada kelas uji coba (kelas V SDN Lamper Tengah 02 Semarang) sehingga soal tersebut memenuhi syarat sebagai soal evaluasi yaitu valid, reliabel, daya pembeda, dan memiliki taraf kesukarang yang sesuai. Setelah soal pretest diberikan, pada uji normalitasn awal dengan menggunakan uji Liliefors. Uji normalitas dinilai pretest siswa kelas $V$ dengan $n=17$ dan $\alpha=0,05$ memiliki hasil harga $L_{0}<$ Llabel yaitu $0,153<0,206$ maka kelas yang telah menempuh pretest berasal dari populasi yang berdistruibusi normal.

Penelitian ini dilaksanakan pada semester ganjil bulan September 2019 diSDN Kaliwiru Semarang pada siswa kelas V dengan jumlah 17 siswa. Sebelum melaksanakan penelitian, peneliti melaksanakan studi pendahuluan untuk mengetahui permasalahan yang ada dikelas dan diperoleh informasi bahwa dalam proses pembelajaran Matematika di kelas guru masih menggunakan model konvensional, selain itu, guru juga jarang menghadirkan media, sehingga pembelajaran yang dilakukan kurang menarik. Akibat yang muncul karena permasalahan tersebut terlihat pada hasil pretest yang memiliki nilai rata-rata rendah dan belum mencapai Kriteria Ketuntasan Minimal (KKM) yang sudah ditentukan yaitu 65. Dari jumlah 17 siswa, 5 siswa tuntas dan 12 siswa belum tuntas.

Peneliti mempersiapkan rencana pelaksanaan pembelajaran yang akan dilaksanakan adalah 2 kali pertemuan dengan 1 RPP. Rencana pembelajaran dilaksanakan dengan menggunakan model pembelajaran Role Playing berbantu media Multiply Cards. Pada hari pertama peneliti membagikan soal sebagai pretest kepada siswa untuk dikerjakan.

Setelah soal pretest dikerjakan dan dikumpulkan guru terlebih dahulu sedikit membahas materi perkalian pecahan. Guru membagi siswa menjadi 4 kelompok yang terdiri dari 4-5 siswa. Pembelajaran menggunakan model pembelajaran Role Playing berbantu media Multiply Cards dimulai dengan meminta siswa untuk duduk melingkar dan bergabung sesuai dengan kelompoknya, setiap kelompok mewakili satu anggota untuk memerankan permainan monopoli. Masing-masing kelompok berdiskusi untuk menyelesaikan media Multiply Cards yang telah didapatkan.

Berdasarkan data hasil penelitian, siswa yang mengikuti pembelajaran menggunakan model pembelajaran Role Playing berbantu media Multiply Cards menjadi lebih semangat untuk mengikuti proses pembelajaran karena diselingi dengan permainan. sehingga siswa yang mengikuti pembelajaran menggunakan model pembelajaran Role Playing berbantu media Multiply Cards memiliki hasil belajar yang lebih tinggi dibandingkan dengan saat menggunakan model pembelajaran konvensional.

Berdasarkan hasil analisis yang telah dilakukan pada data niali pretest dan postest kelas V SDN Kaliwiru Semarang dikatakan bahwa hasil belajar siswa berdistribusi normal. Hasil uji-t satu pihak dimana $t_{\text {hitung }}$ yang sudah didapatkan dikonsultasikan dengan $t_{\text {hutung }}>t_{\text {tabel }}$ yaitu 6,881 $>2,035$ maka kesimpulannya adalah hasil belajar siswa yang menempuh postest lebih baik daripadda ketika menempuh pretest setelah menggunakan model Role Playing berbantu media Multiply Cards pada pelajaran matematika kelas V SDN Kaliwiru Semarang. Kemudian ketuntasan belajar individu siswa yang menempuh postest lebih tinggi dari pada siswa yang menempuh pretest dengan pencapaian 13 siswa untuk postest dan 5 siswa untuk pretest. Selanjutnya ketuntasan belajar klasikal didapat hasil belajar siswa setelah menempuh postest memiliki persentase ketuntasan 76,5\%, hal ini pencapaian ketuntasan klasikal setelah menempuh postest lebih dari 75\%. Sedangkan siswa yang menempuh pretest ketuntasan belajar klasikal mendapatkan persentase 29,4\%.

Berdasarkan hasil penelitian, semua permasalahan yang melatar belakangi pelaksanaan penelitian ini dapat terjawab dan terpecahkan dengan penjelasan pembahasan diatas. Sehingga hipotesis dan tujuan penelitian dapat tercapai, yaitu adanya keefektifan model Role Playing berbantu media Multiply Cards terhadap hasil belajar matematika kelas V SDN Kaliwiru Semarang. Matematika merupakan ilmu mempunyai peran penting dalam berbagai disiplun dan memajukan daya pikir manusia. Akan tetapi masih banyak sisa yang menghindari matematika sebagai mata pelajaran yang sulit dipahami. Sehingga diperlukan oembelajaran inovatif yaitu pembelajatan Role Playing berbantu media Multiply Cards.

\section{Simpulan dan Saran}

Berdasarkan penelitian dan pembahasan dalam penelitian ini dapat disimpulkan bahwa model Role Playing berbantu media Multiply Cards efektif terhadap hasil belajar siswa dalam materi operasi hitung pecahan kelas V SDN Kaliwiru Semarang. Hal ini dibuktikan dari hasil Uji t dimana diperoleh $t_{\text {hitung }}>t_{\text {tabel }}$ atau 6,881 > 2,035 dengan rata-rata nilai dari 51,471 menjadi 81,647. Ketuntasan belajar individu kelas eksperimen telah mencapai rata-rata nilai lebih dari 65 dengan 13 dari 17 siswa tuntas secara individu. Selanjutnya berdasarkan ketuntasan belajar klasikal persentase jumlah siswa yang tuntas secara klasikal 
pada siswa yang menempuh postest telah melampaui $75 \%$ dengan persentase ketuntasan siswa mencapai 76,5\% dari 17 siswa.

Berdasarkan hasil penelitian, maka saran yang dapat diajukan adalah sebagai berikut : 1) Saran untuk guru yaitu pembelajran dengan menggunakan model pembelajran Role Playing berbantu media Multiply Cards dapat dilaksanakn dalam proses belajar mengajar sebagai variasi mengajar sehingga tidak monoton dan mencapai kreatifitas pada siswa serta percaya diri dalam pembelajaran. Model pembelajaran Role Playing berbantu media Multiply Cards sudah terbukti dapat meningkatkan hasil belajar siswa. 2) Model pembelajaran Role Playing berbantu media Multiply Cards direkomendasikan penulis untuk terus dikembangkan agar siswa tertarik dan termotivasi. Khususnya untuk mengajar mata pelajaran matematika yang memerlukan variasi mengajar ayang bukan hanya sekedar ceramah. Model pembelajran Role Playing berbantu media Multiply Crads dapat dilakukan untuk menciptakan pembelajaran yang bermakda dan menyenangkan serta membuat siswa lebih memahami materi yang disampaikan.

\section{Daftar Rujukan}

Aqib, Z. (2013). Model-Model, Media, dan Strategi Pembelajaran Kontekstual (Inovatif). Yrama Widya.

Depdiknas. (2007). Rencana strategis Departement Pendidikan Nasional 2005 - 2009. Pusat Informasi dan Humas Departemen Pendidikan Nasional.

Djamarah, S. B. dan Z. A. (2010). Strategi Belajar Mengajar. PT Rineka Cipta.

Ernani, A. S. (2016). Mata Pelajaran Bahasa Indonesia Kelas V di Madrasah Ibtidaiyah Wathoniyah. JIP: Jurnal Ilmiah PGMI, 2, 29-42.

Hamdani. (2011). Strategi Belajar Mengajar. Pustaka Setia.

Niken, Susanto, T. B. S. (2012). Penerapan Pembelajaran Matematika Melalui Model Pembelajaran Reciprocal Dalam Mengatasi Kesalahan Siswa Menyelesaikan Soal Matematika Kelas IX Smp N 1 Pakusari Pokok Bahasan Statistika Semester Ganjil Tahun Ajaran 2012/2013. Kadikma, 3(3), 95108.

Nurhasanah, I. A., Sujana, A., \& Sudin, A. (2016). Penerapan Metode Role Playing Untuk Meningkatkan Hasil Belajar Siswa Pada Materi Hubungan Mahluk Hidup Dengan Lingkungannya. Penerapan Metode Role Playing Untuk Meningkatkan Hasil Belajar Siswa Pada Materi Hubungan Mahluk Hidup Dengan Lingkungannya, 1(1), 611-620. https://doi.org/10.23819/pi.v1i1.2992

Rini, N. P., Shodiqin, A., \& Damayani, A. T. (2019). Keefektifan Model Pembelajaran ICM dan Bertukar Pasangan Berbantuan Media Kartu Angka terhadap Kemampuan Pemecahan Masalah Matematika. Jurnal Ilmiah Sekolah Dasar, 3(1), 1-9. https://doi.org/10.23887/jisd.v3i1.17173

Roestiyah. (2012). Strategi Belajar Mengajar. Rineka Cipta.

Sha'adhah, Z., Hobri, \& Setiawan, T. B. (2013). Penerapan Metode Role Playing (Bermain Peran) untuk Mengurangi Kesalahan Siswa dalam Menyelesaikan Soal Pada Materi Aritmetika Sosial Kelas VII A SMPN 1 Sukowonoso Semester Ganjil Tahun Ajaran 2012/2013. Kadikma, 4(2), 27-38.

Sudharto, dkk. (2009). Pengantar Pendidikan. FIP IKIP PGRI Semarang.

Sugiyono. (2017). Statistiak untuk Penelitian. Alfabeta.

Sumaatmadja, N. dkk. (2007). Konsep Dasar IPS. Jakarta: Depdiknas UT.

Sundayana, R. (2013). Media Pembelajaran Matematika. Alfabeta.

Tarigan, A. (2017). Penerapan Model Pembelajaran Role Playing Untuk Meningkatkan Hasil Belajar Ips Siswa Kelas Iii Sd Negeri 013 Lubuk Kembang Sari Kecamatan Ukui. Primary: Jurnal Pendidikan Guru Sekolah Dasar, 5(3), 102. https://doi.org/10.33578/jpfkip.v5i3.3898 